\title{
Oxidation of triethylene glycol and tetraethylene glycol by ditelluratocuprate(III) in alkaline medium - A kinetic and mechanistic study
}

\author{
Jinhuan Shan * and Yi Li \\ College of Chemistry and Environmental Science, Hebei University, Baoding 071002, China \\ ${ }^{*}$ Corresponding author at: College of Chemistry and Environmental Science, Hebei University, Baoding 071002, China. \\ Tel.: +86.0312.5971129; fax: +86.0312.5079525. E-mail address: shanjinhuaner@yahoo.com.cn (J. Shan).
}

ARTICLE INFORMATION
Received: 20 March 2013
Received in revised form: 21 April 2013
Accepted: 23 April 2013
Online: 30 September 2013
KEYWORDS
Kinetic
Oxidation
Mechanism
Triethylene glycol
Tetraethylene glycol
Ditelluratocuprate(III)

\section{Introduction}

Triethylene glycol (TEG) is a colorless liquid with sweetish smell. It is mainly used as textile auxiliaries, plasticizing agent, diesel fuel additives, rocket fuel and so on. In addition, it has a wide range of applications in many fields, such as medicine, coating, textile, printing, dyeing, papermaking, cosmetics, metal processing, etc. But TEG is toxic, some researches demonstrated that the acute lethal toxicity of TEG had bad effect on skin and eye [1,2]. Tetraethylene glycol (TTEG) is a colorless viscous liquid. It can mixed dissolve with water, ethanol, hydrocarbon and oils. TTEG's production and used as a solvent, plasticizer, lubricant, softening agent for paper tissue, a ceramic paste [3] printing ink binder and a liquid desiccant for natural gas. Moreover, tetraethylene glycol to the eye and the upper respiratory tract has slightly stimulation [4].

Since Vrtis [5] successfully prepared and isolated $\mathrm{Cu}(\mathrm{III})$ complex, more and more researchers have been interested in the study of the higher oxidation state of transition metal which can be stabilized by chelation with polydentate ligands, such as ditelluratocuprate(III) [6,7], diperiodatocuprate(III) [8,9], diperiodatoargentate(III) [10,11], ditelluratoargentate(III) [12], diperiodatonickelate(IV) [13] are good oxidants in a medium with an appropriate $\mathrm{pH}$. Now, $\mathrm{Cu}(\mathrm{III})$ complex is regarded as very effective and interesting oxidising agent. In addition, the use of $\mathrm{Cu}(\mathrm{III})$ not only plays an prominent role in many biological systems [14,15], but also makes contribution as an oxidation agent in organic mixture qualitative analysis [16]. Hence, the further research of $\mathrm{Cu}(\mathrm{III})$ has significance.

In this paper, the kinetics and mechanism of oxidation of triethylene glycol and tetraethylene glycol by ditellurato cuprate(III) (DTC) were studied in detail.

\section{Experimental}

\subsection{Materials}

All chemicals used were of A.R. grade and double distilled water was used throughout the work. Ditelluratocuprate(III) (DTC) was prepared and standardized by the method reported $[17,18]$. The purity of the complex was checked by comparing UV-Vis spectrum with literature data, which showed a characteristic absorption peak at $405 \mathrm{~nm} . \mathrm{KNO}_{3}$ and $\mathrm{KOH}$ were used to maintain ionic strength and alkalinity of the reaction, respectively. Besides, solutions of DTC and reductants were always freshly prepared before using.

\subsection{Kinetics measurements and apparatus}

The kinetics was followed under pseudo-first order conditions by keeping a large excess of [reductant] with respect to [DTC]. Solution $(2 \mathrm{~mL})$ containing required concentration of $\mathrm{DTC}, \mathrm{OH}^{-}, \mathrm{TeO}_{4}{ }^{2-}$ was mixed with solution $(2 \mathrm{~mL})$ requisite concentration of reductant and ionic strength at the desired temperature. With the complete fading of DTC color (yellowness) marked the completion of the reaction. The kinetic measurements were performed on a UV-vis spectrophotometer (TU-1900, Beijing Puxi Inc., China), which had a cell holder kept at constant temperature $\left( \pm 0.1{ }^{\circ} \mathrm{C}\right)$ by circulating water from a thermostat (DC-2010, Baoding Xinhua Inc., China). It was verified that there was negligible interference from other reagents at $405 \mathrm{~nm}$. The product of oxidation was identified as aldehyde by its characteristic spot test [19]. 


\section{Results and discussion}

\subsection{Evaluation of pseudo-first order rate constants}

Under the conditions of [reductant $]_{0}$ ( $[\text { TEG }]_{0}$ and $[\text { TTEG }]_{0}$ ) $>>[\mathrm{Cu}(\mathrm{III})]_{0}$, the plots of $\ln \left(\mathrm{A}_{\mathrm{t}}-\mathrm{A}_{\infty}\right)$ versus time were straight lines( $r \geq 0.998)$, indicating the reaction was first order in DTC. The pseudo-first-order rate constants $k_{o b s}$ were evaluated by using the equation $\ln \left(\mathrm{A}_{\mathrm{t}}-\mathrm{A}_{\infty}\right)=-k_{o b s} \mathrm{t}+\mathrm{b}$ (constant). The $k_{\text {obs }}$ values were the average value of at least three independent experiments, and reproducibility was within $\pm 5 \%$.

\subsection{Rate dependence on the [reductant]}

At fixed concentration of $\mathrm{Cu}(\mathrm{III}), \mathrm{OH}^{-}, \mathrm{TeO}_{4}{ }^{2-}$ and ionic strength $\mu$, the values of $k_{\text {obs }}$ were determined at different temperatures. The order $n_{a p}$ of [reductant] ([TEG] and [TTEG]) was calculated as fractional order form the slopes of ln $k_{\text {obs }}$ versus In [reductant] plots. Besides, the $k_{\text {obs }}$ value increased with the increasing [reductant]. The plots of $k_{\mathrm{obs}^{-1}}$ versus [reductant] ${ }^{-1}$ were straight lines $(r \geq 0.998)$ (Figure 1 and Figure 2).

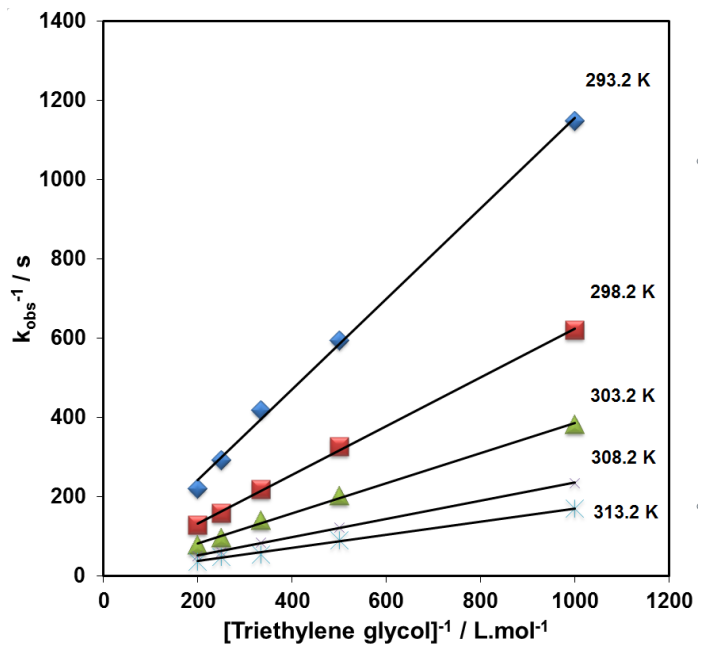

Figure 1. Plots of $k_{o b s}{ }^{-1} v s$. [Triethylene glycol] ${ }^{-1}$ [ [DTC] $=7.16 \times 10^{-5} \mathrm{~mol} / \mathrm{L}$, $\left[\mathrm{TeO}_{4}{ }^{2}\right]=1.00 \times 10^{-2} \mathrm{~mol} / \mathrm{L},\left[\mathrm{OH}^{-}\right]=1.00 \times 10^{-2} \mathrm{~mol} / \mathrm{L}(r \geq 0.998)$.

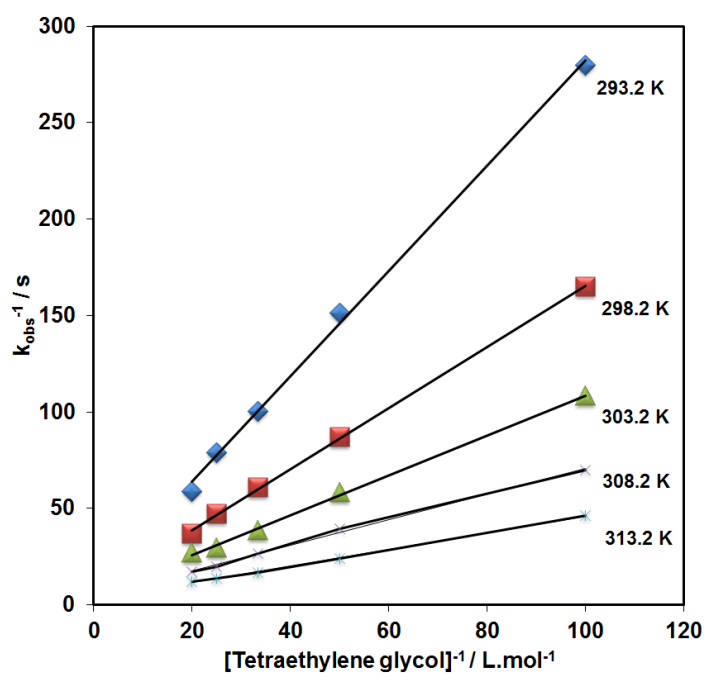

Figure 2. Plots of $k_{o b s}{ }^{-1}$ vs. [Tetraethylene glycol] ${ }^{-1}$; [DTC] $=7.16 \times 10^{-5} \mathrm{~mol} / \mathrm{L}$, $\left[\mathrm{TeO}_{4}{ }^{2-}\right]=1.00 \times 10^{-2} \mathrm{~mol} / \mathrm{L},\left[\mathrm{OH}^{-}\right]=1.00 \times 10^{-2} \mathrm{~mol} / \mathrm{L}(r \geq 0.998)$.

\subsection{Rate dependence on the [OH-]}

The effect of $\left[\mathrm{OH}^{-}\right]$on the reaction has been studied in the range of $0.50 \times 10^{-2}$ to $2.50 \times 10^{-2} \mathrm{~mol} / \mathrm{L}$ at constant [DTC], [reductant], [ $\mathrm{TeO}_{4}{ }^{2}$ ], $\mu$ and temperature. It was found that $k_{\mathrm{obs}}$ values increased with the increaseing [ $\left.\mathrm{OH}^{-}\right]$(Table 1) and the order with respect to [OH-] was fractional. The plot of $k_{\mathrm{obs}}{ }^{-1} v s$. $\left[\mathrm{OH}^{-}\right]^{-1}$ was linear with a positive intercept $(r \geq 0.998)$.

\subsection{Rate dependence on the $\left[\mathrm{TeO}_{4}{ }^{2-}\right]$}

The $\left[\mathrm{TeO}_{4}{ }^{2-}\right]$ was varied from $0.50 \times 10^{-3}$ to $2.50 \times 10^{-3} \mathrm{~mol} / \mathrm{L}$ range at constant [DTC], [reductant], [OH-], $\mu$ and temperature. The $k_{\text {obs }}$ values increased with the decreasing concentration of $\mathrm{TeO}_{4}{ }^{2-}$ (Table 1). The order with respect to $\mathrm{TeO}_{4}{ }^{2-}$ was found to be a negative fraction, which reveals that $\mathrm{TeO}_{4}{ }^{2-}$ is produced in equilibrium before the rate controlling step. A plot of $k_{\mathrm{obs}}{ }^{-1}$ versus $10^{2}\left[\mathrm{TeO}_{4}{ }^{2-}\right]$ was straight line with a positive intercept $(r$ $\geq 0.997)$.

\subsection{Rate dependence on ionic strength $\mu$}

The effect of ionic strength on the reaction was studied in the range of $1.50 \times 10^{-2} \mathrm{~mol} / \mathrm{L}$ to $7.50 \times 10^{-2} \mathrm{~mol} / \mathrm{L}$ at constant [DTC], [reductant], [OH-], [ $\left.\mathrm{TeO}_{4}^{2-}\right]$ and temperature. The experimental results indicated that the rate constant decreased with the increasing of ionic strength (Table 1), which showed that there was negative salt that consistent with the common regulation of the kinetics [20].

\subsection{Free radical detection}

To study the possible presence of a free radical during the reaction, a known amount of acrylamide was added under the protection of nitrogen atmosphere. The polymerization clearly appeared which indicated that free radical intermediates may be produced in the oxidation by DTC. And blank experiments in reaction system gave no polymeric suspensions.

\subsection{Reaction mechanism}

In the alkaline medium, the electric dissociation equilibrium of telluric acid was given earlier (here $\mathrm{pK}_{\mathrm{w}}=14$ ).

$$
\begin{aligned}
& \mathrm{H}_{5} \mathrm{TeO}_{6}{ }^{-}+\mathrm{OH}^{-} \rightleftharpoons \mathrm{H}_{4} \mathrm{TeO}_{6}{ }^{2-}+\mathrm{H}_{2} \mathrm{O} \log \beta_{1}=3.049 \\
& \mathrm{H}_{4} \mathrm{TeO}_{6}{ }^{2-}+\mathrm{OH}^{-} \rightleftharpoons \mathrm{H}_{3} \mathrm{TeO}_{6}{ }^{3-}+\mathrm{H}_{2} \mathrm{O} \quad \log \beta_{2}=-1.000
\end{aligned}
$$

From equilibriums (1)-(2), The distribution of all species of tellurate can be calculated in aqueous alkaline solution. In alkaline medium such as $\left[\mathrm{OH}^{-}\right]=0.01 \mathrm{~mol} / \mathrm{L},\left[\mathrm{H}_{4} \mathrm{TeO}_{6}{ }^{2-}\right.$ ]:[ $\left.\mathrm{H}_{5} \mathrm{TeO}_{6}{ }^{-}\right]:\left[\mathrm{H}_{3} \mathrm{TeO}_{6}{ }^{3-}\right]=1000: 89: 1$. Hence, in the concentration of $\mathrm{OH}^{-}$range used in this work, the $\mathrm{H}_{5} \mathrm{TeO}_{6}{ }^{-}$and $\mathrm{H}_{3} \mathrm{TeO}_{6}{ }^{3-}$ species can be neglected, and the main tellurate species was $\mathrm{H}_{4} \mathrm{TeO}_{6}{ }^{2-}$.

The fractional order in $\mathrm{OH}^{-}$determined that $\mathrm{OH}^{-}$took part in a pre-equilibrium with $\mathrm{Cu}(\mathrm{III})$ before the rate-determing step. The plot of $k_{\mathrm{obs}^{-1}}$ versus [ $\mathrm{TeO}_{4}{ }^{2-}$ ] was line with a positive intercept indicating a dissociation equilibrium in which the $\mathrm{Cu}$ (III) lost a tellurate ligand $\mathrm{H}_{4} \mathrm{TeO}_{6}{ }^{2-}$ from its coordination sphere forming a active specie monotelluratocuprate(III) complex (MTC). The order with respect to reductant was fractional, which indicated complex formation between reductant and MTC. In alkaline solution, $\left(\mathrm{H}_{2} \mathrm{TeO}_{6}\right)_{4}^{-}$protonated easily and formed $\left[\mathrm{Cu}\left(\mathrm{H}_{4} \mathrm{TeO}_{6}\right)_{2}\right]^{-}$by coordinating with central ion.

The plausible mechanism of oxidation was proposed as follows (Equation 3-6) (R, respectively stand for $\mathrm{CH}_{2} \mathrm{O}\left(\mathrm{CH}_{2}\right)_{2} \mathrm{OCH}_{2}$ and $\left.\mathrm{CH}_{2} \mathrm{O}\left(\mathrm{CH}_{2}\right)_{2} \mathrm{O}\left(\mathrm{CH}_{2}\right)_{2} \mathrm{OCH}_{2}\right)$. 


\begin{tabular}{|c|c|c|c|c|c|c|}
\hline $10^{5}[\mathrm{DTC}],(\mathrm{mol} / \mathrm{L})$ & [Reductant], (mol/L) & $\mu \times 10^{2},(\mathrm{~mol} / \mathrm{L})$ & $10^{3}\left[\mathrm{TeO}_{4}^{2}-\right],(\mathrm{mol} / \mathrm{L})$ & $10^{3}[\mathrm{OH}],(\mathrm{mol} / \mathrm{L})$ & TEG, $10^{3} k_{o b s} / s^{-1}$ & TTEG, $10^{3} k_{o b s} / \mathbf{s}^{-1}$ \\
\hline 7.16 & 0.01 & 3.80 & 1.00 & 5.00 & 8.15 & 2.95 \\
\hline 7.16 & 0.01 & 3.80 & 1.00 & 10.00 & 9.33 & 3.70 \\
\hline 7.16 & 0.01 & 3.80 & 1.00 & 15.00 & 9.63 & 4.12 \\
\hline 7.16 & 0.01 & 3.80 & 1.00 & 20.00 & 9.84 & 4.38 \\
\hline 7.16 & 0.01 & 3.80 & 1.00 & 25.00 & 10.03 & 4.52 \\
\hline 7.16 & 0.01 & 3.80 & 0.50 & 10.00 & 15.79 & 4.68 \\
\hline 7.16 & 0.01 & 3.80 & 1.00 & 10.00 & 12.06 & 3.75 \\
\hline 7.16 & 0.01 & 3.80 & 1.50 & 10.00 & 9.33 & 3.10 \\
\hline 7.16 & 0.01 & 3.80 & 2.00 & 10.00 & 8.32 & 2.74 \\
\hline 7.16 & 0.01 & 3.80 & 2.50 & 10.00 & 7.18 & 2.46 \\
\hline 7.16 & 0.01 & 1.50 & 1.00 & 10.00 & 12.16 & 4.37 \\
\hline 7.16 & 0.01 & 3.00 & 1.00 & 10.00 & 11.14 & 3.82 \\
\hline 7.16 & 0.01 & 4.50 & 1.00 & 10.00 & 10.96 & 3.63 \\
\hline 7.16 & 0.01 & 6.00 & 1.00 & 10.00 & 9.56 & 3.20 \\
\hline 7.16 & 0.01 & 7.50 & 1.00 & 10.00 & 8.22 & 2.93 \\
\hline
\end{tabular}

Table 2. Rate constants (k) and the activation parameters for the rate-determining step *.

\begin{tabular}{|c|c|c|c|c|c|c|}
\hline $\mathrm{T}(\mathrm{K})$ & & 293.2 & 298.2 & 303.2 & 308.2 & 313.2 \\
\hline \multirow{2}{*}{$10^{2} \mathrm{k} / \mathrm{s}^{-1}$} & TEG & 3.89 & 5.23 & 7.21 & 9.45 & 11.83 \\
\hline & TTEG & 5.48 & 7.13 & 9.73 & 11.61 & 16.62 \\
\hline $\begin{array}{l}\text { Thermodynamic } \\
\text { activation parameters }\end{array}$ & $\begin{array}{l}\text { TEG } \\
\text { TTEG }\end{array}$ & $\begin{array}{l}E_{\mathrm{a}}(\mathrm{kJ} / \\
E_{\mathrm{a}}(\mathrm{kJ} /\end{array}$ & $\begin{array}{l}\neq(\mathrm{kJ} / \mathrm{m} \\
\neq(\mathrm{kJ} / \mathrm{m}\end{array}$ & $\begin{array}{l}\mathrm{O} / \mathrm{J} / \mathrm{K} \cdot \mathrm{mo} \\
\mathrm{O} / \mathrm{K} \cdot \mathrm{Ko} \\
\end{array}$ & & \\
\hline
\end{tabular}

$$
\begin{aligned}
& {\left[\mathrm{Cu}\left(\mathrm{H}_{4} \mathrm{TeO}_{6}\right)_{2}\right]^{-}+\mathrm{OH}^{-} \stackrel{K_{1}}{\rightleftharpoons}\left[\mathrm{Cu}\left(\mathrm{H}_{3} \mathrm{TeO}_{6}\right)\right]+\mathrm{H}_{4} \mathrm{TeO}_{6}{ }^{2-}+\mathrm{H}_{2} \mathrm{O}} \\
& {\left[\mathrm{Cu}\left(\mathrm{H}_{3} \mathrm{TeO}_{6}\right)\right]+\mathrm{HOCH}_{2} \mathrm{RCH}_{2} \mathrm{OH} \stackrel{K_{2}}{\rightleftharpoons}\left[\mathrm{Cu}\left(\mathrm{H}_{3} \mathrm{TeO}_{6}\right)\left(\mathrm{HOCH}_{2} \mathrm{RCH}_{2} \mathrm{OH}\right)\right]} \\
& {\left[\mathrm{Cu}\left(\mathrm{H}_{3} \mathrm{TeO}_{6}\right)\left(\mathrm{HOCH}_{2} \mathrm{RCH}_{2} \mathrm{OH}\right)\right] \frac{k}{\text { slow }} \mathrm{Cu}(\mathrm{II})+\bullet \mathrm{CH}(\mathrm{HO}) \mathrm{RCH}_{2} \mathrm{OH}} \\
& \mathrm{Cu}^{*}(\mathrm{III})+\mathrm{OH}^{-}+\bullet \mathrm{CH}(\mathrm{HO}) \mathrm{RCH}_{2} \mathrm{OH} \underset{\frac{k_{f}}{\text { fast }}}{\longrightarrow} \mathrm{OCHRCH}_{2} \mathrm{OH}+\mathrm{Cu}(\mathrm{II})+\mathrm{H}_{2} \mathrm{O}
\end{aligned}
$$

The $\mathrm{Cu}^{*}(\mathrm{III})$ standed for any kind of which $\mathrm{Cu}^{3+}$ existed in equilibrium. The total concentration of $\mathrm{Cu}(\mathrm{III}) \mathrm{can}$ be written as: (subscripts $\mathrm{T}$ and e stand for total concentration and equilibrium concentration respectively).

$$
\begin{aligned}
{[\mathrm{Cu}(\mathrm{III})]_{\mathrm{t}}=} & {\left[\mathrm{Cu}\left(\mathrm{H}_{4} \mathrm{TeO}_{6}\right)_{2}\right]_{\mathrm{e}}^{-}+\left[\mathrm{Cu}\left(\mathrm{H}_{3} \mathrm{TeO}_{6}\right)\right]_{\mathrm{e}} } \\
& +\left[\mathrm{Cu}\left(\mathrm{H}_{3} \mathrm{TeO}_{6}\right)\left(\mathrm{HOCH}_{2} \mathrm{RCH}_{2} \mathrm{OH}\right)\right]_{\mathrm{e}}
\end{aligned}
$$

Since reaction (5) was the rate-determining step, the rate of disappear of $[\mathrm{Cu}(\mathrm{III})]_{\mathrm{t}}$ was represented as:

$$
\begin{aligned}
& -\frac{\mathrm{d}[\mathrm{Cu}(\mathrm{III})]_{\mathrm{t}}}{\mathrm{dt}}=2 k\left[\mathrm{Cu}\left(\mathrm{H}_{3} \mathrm{TeO}_{6}\right)\left(\mathrm{HOCH}_{2} \mathrm{RCH}_{2} \mathrm{OH}\right)\right] \\
& -\frac{\mathrm{d}[\mathrm{Cu}(\mathrm{III})]_{\mathrm{t}}}{\mathrm{dt}}= \\
& =\frac{2 k K_{1} K_{2}\left[\mathrm{OH}^{-}\right]\left[\mathrm{HOCH}_{2} \mathrm{RCH}_{2} \mathrm{OH}\right][\mathrm{Cu}(\mathrm{III})]}{\left[\mathrm{H}_{4} \mathrm{TeO}_{6}^{2-}\right]+K_{l}\left[\mathrm{OH}^{-}\right]+K_{1} K_{2}\left[\mathrm{OH}^{-}\right]\left[\mathrm{HOCH}_{2} \mathrm{RCH}_{2} \mathrm{OH}\right]}= \\
& =k_{\text {obs }}[\mathrm{Cu}(\mathrm{III})]
\end{aligned}
$$

$k_{o b s}=\frac{2 k K_{1} K_{2}\left[\mathrm{OH}^{-}\right]\left[\mathrm{HOCH}_{2} \mathrm{RCH}_{2} \mathrm{OH}\right]}{\left[\mathrm{H}_{4} \mathrm{TeO}_{6}{ }^{2-}\right]+K_{1}\left[\mathrm{OH}^{-}\right]+K_{1} K_{2}\left[\mathrm{OH}^{-}\right]\left[\mathrm{HOCH}_{2} \mathrm{RCH}_{2} \mathrm{OH}\right]}$
Re-arranging equation (10) led to equation $(11,12)$.

$$
\begin{gathered}
\frac{1}{k_{\text {obs }}}=\frac{1}{2 k}+\frac{\left[\mathrm{H}_{4} \mathrm{TeO}_{6}{ }^{2-}\right]+K_{1}\left[\mathrm{OH}^{-}\right]}{2 k K_{1} K_{2}\left[\mathrm{OH}^{-}\right]} \times \frac{1}{\left[\mathrm{HOCH}_{2} \mathrm{RCH}_{2} \mathrm{OH}\right]} \\
\frac{1}{k_{\text {obs }}}=\frac{1+K_{2}\left[\mathrm{HOCH}_{2} \mathrm{RCH}_{2} \mathrm{OH}\right]}{2 k K_{2}\left[\mathrm{HOCH}_{2} \mathrm{RCH}_{2} \mathrm{OH}\right]} \\
+\frac{\left[\mathrm{H}_{4} \mathrm{TeO}_{6}{ }^{2-}\right]}{2 k K_{1} K_{2}\left[\mathrm{HOCH}_{2} \mathrm{RCH}_{2} \mathrm{OH}\right]} \times \frac{1}{\left[\mathrm{OH}^{-}\right]}
\end{gathered}
$$

From the equation (9), the order with respect to $\mathrm{Cu}(\mathrm{III})$ was unity. The equation (11) suggested that the rate constants of the rate-determining step at different temperature were determined by the intercept of the plots $k_{\mathrm{obs}}{ }^{-1}$ vs [reductant]-1 which were straight lines. Equation (12) indicated that the plots of $k_{o b s}{ }^{-1} v s\left[\mathrm{OH}^{-}\right]^{-1}$ and $k_{o b s}{ }^{-1} v s\left[\mathrm{H}_{4} \mathrm{TeO}_{6}{ }^{2-}\right]$ were straight lines. In addition, activation energy and the thermodynamic parameters were evaluated at $298.2 \mathrm{~K}$ by the method given earlier (Table 2).

\section{Conclusion}

In this study, we found that both the triethylene glycol (TEG) and tetraethylene glycol (TTEG) formed the same intermediate compounds with $\mathrm{Cu}(\mathrm{III})$ in the reaction system, which could be due to their similar structure. In addition, the values of the activation parameters with respect to TEG was 
larger than that of TTEG, which indicated the reactivity of TTEG was higher than TEG. The reason was that the electrondonating ability of TTEG was larger than that of TEG, which indicated the former was more stable than the latter. The above conclusions were consistent with experimental results.

\section{Acknowledgement}

This work was supported by a research grant from College of Chemistry and Environmental Science of Hebei University.

\section{References}

[1]. Bryan, B.; William, M. S. J. Appl. Toxicol. 2007, 27, 291-299.

[2]. Bryan, B.; William, M. S.; James, C. N. J. Appl. Toxicol. 2006, 26, 387396.

[3]. Borcard, F.; Staedler, D.; Comas, H.; Juillerat, F. K.; Sturzenegger, P. N.; Heuberger, R.; Gonzenbach, U. T.; Juillerat, L.; Gerber, S. J. Med. Chem. 2012, 55(18), 7988-7997.

[4]. Schladt, L.; Ivens, I.; Karbe, E.; RuhlFehlert, C.; Bomhard, E. Exp. Toxicol. Pathol. 1998, 50(3), 257-265.

[5]. Vrtis, M. Rec. Trav. Chim. 1925, 44, 425-434.

[6]. Shan, J. H.; Wang, L. P.; Shen, S. G.; Sun, H. W. Turk. J. Chem. 2003, 27, 265-272.

[7]. Shan, J. H.; Liu, Y. P.; Shen, H. X.; Zhang, J. Y.; Yang, Y. F. Int. J. Chem. 2011, 3(2), 111-116.

[8]. Naik, K. M.; Nandibewoor, S. T. Oxid. Commun. 2012, 35, 545-559.

[9]. Shan, J. H.; Wang, X. Q.; Zhao, N. Chinese J. Chem. 2010, 28(7), 10811084.

[10]. Ragunatharaddi, R. H.; Nagaraj, P. S.; Sharanappa, T. N. J. Phys. Org. Chem. 2009, 22(3), 234-240.

[11]. Jayant, I. G.; Sanjeevaraddi, R. S.; Sharanappa, T. N. Cat. Sci. Tec. 2012, 2, 2549-2557.

[12]. Shan, J. H.; Huo, S. H.; Shen, S. G.; Sun, H. W.; Wang, A. Z. Chem. J. Chinese U. 2005, 26(4), 706-709.

[13]. Shan, J. H.; Shen, H. X.; Wang, H. Y.; Wang, X. Q. Oxid. Commun. 2012, 35, 583-590.

[14]. Fouzia, S. R.; Hummara, N.; Ehsanullwadood, K. Pak. J. Bio. Sci. 2000, 3(2), 354-355.

[15]. April, D. J.; Guowen, P.; Michael, F. G. M.; Emily, A. L.; Colin, J. M.; Georgios, K.; Manos, M.; Charles, H. S. ACS Nano 2012, 6(11), 1011510121.

[16]. Reddy, K. B.; Sethuram, B.; Rao, T. N. Indian J. Chem. 1981, 20A, 272275.

[17]. Chandra, S.; Yadava, K. L. Talanta 1968, 15, 349-352.

[18]. Jaiswal, P. K.; Yadava, K. L. Indian J. Chem. 1973, 11, 837-838.

[19]. Feigl, F. Spot Tests In Organic Analysis, Elsevier Publishing Co., New York, 1966.

[20]. Jin, J. J. Kinetics Principle of Chemical Reaction in Liquid Phase, Science Technique Press, Shanghai, 1966. 